Eur. J. Clin. Chem. Clin. Biochem.

Vol. 32, 1994, pp. 893-899

(c) 1994 Walter de Gruyter \& Co. Berlin - New York

\title{
Immunoenzymometric Assays for Alkaline Protease and Exotoxin A from Pseudomonas aeruginosa: Development and Use in Detecting Exoproteins in Clinical Isolates from Patients with Cystic Fibrosis ${ }^{1}$ )
}

\author{
By M.-C. Jaffar-Bandjee ${ }^{1}, J$. Carrère ${ }^{1}$, M. Bally ${ }^{2}, O$. Guy-Crotte $^{3}$ and C. Galabert ${ }^{1}$ \\ 1 Laboratoire de Biochimie, CERM, Hôpital Renée Sabran, Giens, Hyères Cedex, France \\ ${ }^{2}$ Laboratoire d'Ingéniérie et Dynamique des Systèmes Membranaires, CNRS, Marseille Cedex 20, France \\ 3 Groupe de Recherche sur les Glandes Exocrines, Faculté de Médecine, Marseille Cedex 05, France
}

(Received February 7/August 1, 1994)

Summary: Using immunoenzymometric assays, the production of elastase, alkaline protease and exotoxin A was determined in culture supernatants of 35 strains of Pseudomonas aeruginosa isolated from patients suffering from cystic fibrosis. The assays were simple, specific, sensitive and reproducible, and permitted the determination of low levels of exoproteins. A large strain variability of exoprotein production was found. Most of the strains secreted all three exoproteins, but six out of the 35 strains $(17 \%)$ did not secrete at least one of the three $(<0.3 \mu \mathrm{g} / \mathrm{l})$. A significant correlation was observed between elastase and exotoxin A productions $(r=0.697, p<0.001)$.

\section{Introduction}

The pathogenic substances of Pseudomonas aeruginosa include chemoattractant factor, endotoxin and numerous exoproducts such as exotoxins, proteases, ${ }^{2}$ ) phospholipase and leucocidin (1). In disease states such as cystic fibrosis, many clinical isolates are positive for alkaline protease, elastase ${ }^{2}$ ) and exotoxin $\mathrm{A}^{2}$ ) production (2-4). These enzymes have been implicated as important factors contributing directly or indirectly to the pathogenicity of this microorganism in lung diseases $(5-10)$. Patients with cystic fibrosis have a high prevalence of Pseudomonas aeruginosa colonization, which rapidly causes a chronic infection of the mucosal surface of the

\footnotetext{
1) Funding organisations:

Association Française de Lutte contre la Mụcoviscidose (AFLM), and Commission Scientifique de la Recherche des Hospices Civils de Lyon.

2) Enzymes:

Pseudomonas aenuginosa alkaline protease

Pseudomonas aeruginosa elastase, EC 3.4.24

Pseudomonas aeruginosa exotoxin A
}

lung (11). Inhibition of the local immune response by bacterial proteases may provide an environment for bacterial colonization and establishment of chronic infection $(12,13)$. The conditions which allow recurrent, refractory Pseudomonas aeruginosa infection are poorly understood. Some authors (14) have suggested that the production of extracellular enzymes rather than the replication of the bacteria is the important factor of Pseudomonas aeruginosa pathogenicity.

This prompted us to develop easily applicable methods to quantify the production of several of these extracellular enzymes in biological media. A direct immunoassay for exotoxin A has been previously described (15), using antibodies from two different animal species i.e., rabbit antitoxin antibody for the coating of the solid-phase, and horseradish peroxidase-sheep antitoxin antibody for the sandwich partner. Radioimmunoassays have been developed by Cryz \& Iglewski (16) and by Döring et al. (17) to detect alkaline protease and exotoxin A (18). 
We previously described an immunoassay for the detection of elastase which required only one species-specific antibody (19). The present study was devoted to the detection of elastase, alkaline protease and exotoxin $\mathrm{A}$ in culture supernatants of Pseudomonas aeruginosa. To achieve this, we developed new specific enzyme immunoenzymometric assays for alkaline protease and exotoxin $\mathrm{A}$, using rabbit antisera against alkaline protease and against exotoxin $\mathrm{A}$.

\section{Materials and Methods}

\section{Materials}

Thirty five Pseudomonas aeruginosa isolates were obtained from sputum samples from cystic fibrosis patients, hospitalized in the Paediatric Department of Hôpital Renée Sabran (Giens, France).

Strains PAO1 and PA103 were a gift from A. Lazdunski (CNRS, Marseille). PAO1, a well characterized strain, produces most of the recognized Pseudomonas aeruginosa virulence factors. PA103 is an elastase- and alkaline protease-deficient mutant.

The following chemicals and materials were obtained from commercial sources: Pseudomonas aeruginosa alkaline protease $\left(M_{\mathrm{r}}\right.$ 48000 ), specific activity $5.01 \mathrm{mPU} / \mathrm{mg}$ protein, was from Nagase, Osaka, Japan; Exotoxin A $\left(M_{\mathrm{r}} 66000\right)$ was from the Swiss Serum and Vaccine Institute, Bern, Switzerland; Pseudomonas isolation agar and trypticase soya broth were obtained from Difco Laboratories, Detroit, MI, USA; bovine serum albumin and o-phenylenediamine were from Sigma, Saint Louis, MO, USA; Freund's complete and incomplete adjuvant were obtained from the Institut Mérieux, Lyon, France; horseradish peroxidase, grade I, $250 \mathrm{U} / \mathrm{mg}$ was obtained from Boehringer Mannheim, Germany; nitrocellulose was from Schleicher and Schüll; enhanced chemiluminescence Western blotting detection reagents were obtained from Amersham, UK; Chelex 100 and the Trans-Blot cell were from Bio-Rad Laboratories, Richmond, CA, USA; horseradish peroxidase-linked immunoglobulin was from Dakopatts, Glostrup, Denmark, and microtitre plates were from Dynatech Laboratories, Chantilly, VA, USA.

\section{Culture standardization for exoprotein production}

Bronchial secretions collected during chest physiotherapy were immediately homogenized with 2,3-dihydroxy-1,4-dithiolbutane (Digesteur $\left.{ }^{(}\right)$and plated onto Pseudomonas isolation agar medium. One or two colonies were subcultured in $3 \mathrm{ml}$ of trypticase soya broth, enriched with $5 \mathrm{~g} / \mathrm{l}$ yeast extract and $5 \mathrm{~g} / 1$ glucose. The culture was shaken for 6 hours at $30^{\circ} \mathrm{C}$ with maximal aeration. In order to standardize the bacterial growth conditions, an aliquot of this culture was adjusted by dilution in culture medium to a final cell density of $0.5 \times 10^{12} / 1$, corresponding to $2 \mathrm{U}$ McFarland (API system densitometer, Biomérieux, Craponne, France).

For alkaline protease and elastase production, a $1 \mathrm{ml}$ standardized inoculum was added to a $9 \mathrm{ml}$ portion of trypticase soya broth, -enriched with $5 \mathrm{~g} / \mathrm{l}$ yeast extract and $5 \mathrm{~g} / \mathrm{l}$ glucose medium (17). For exotoxin A production, a similar $1 \mathrm{ml}$ inoculum was added to a $9 \mathrm{ml}$ portion of trypticase soya broth dialysate treated with Chelex 100 and supplemented with $10 \mathrm{ml} / 1$ glycerol and 100 $\mathrm{mmol} / \mathrm{l}$ monosodium glutamate $(20)$. The cultures were shaken as described above for 18 hours.

Cultures were centrifuged $(10000 \mathrm{~g})$ for $10 \mathrm{~min}$ at $4^{\circ} \mathrm{C}$ and frozen supernatants were stored at $-80^{\circ} \mathrm{C}$, until use in the immunoassays.
Production of monospecific antisera against alkaline protease and exotoxin $A$

Monospecific antibodies against $P$ seudomonas aeruginosa alkaline protease and exotoxin $\mathrm{A}$ were prepared by the immunization of rabbits.

Antiserum against alkaline protease waş prepared as previously described for elastase (19). Thirty milligrams of purified IgG were obtained from $8 \mathrm{ml}$ of antiserum; the concentration of the antibody was $3.7 \mathrm{~g} / 1$.

For the production of antiserum against exotoxin $\mathrm{A}$, a rabbit was given five successive injections of $10 \mu \mathrm{g}$ of pure enzyme. The first injection was subcutaneous, using enzyme diluted in Freund's complete adjuvant. After 2 weeks; the rabbit received an additional $10 \mu \mathrm{g}$ exotoxin A emulsified with complete adjuvant, via subcutaneous and intramuscular injections, followed every 2 weeks for 2 months by intramuscular injections of $10 \mu \mathrm{g}$ in incomplete adjuvant. The animal was bled one week after the last injection. The IgG fraction of the antiserum was prepared by caprylic acid precipitation using the method of Steinbuch et al. (2i). Sixteen $\mathrm{mg}$ of purified IgG were obtained from $6 \mathrm{ml}$ antiserum; the concentration of the antibody was $2.6 \mathrm{~g} / \mathrm{l}$.

Preparation of the anti-alkaline protease and antiexotoxin A-peroxidase conjugates

For each protein, an immunoglobulin $G$ fraction was used to prepare the enzyme conjugate. Briefly, $1 \mathrm{mg}$ of peroxidase was activated by sodium meta-periodate and coupled to $2 \mathrm{mg}$ of specific rabbit IgG following the procedure of Wilson \& Nakane (22). Immediately after coupling and sodium borohydride reduction, the conjugate was precipitated by adding an equal volume of cold neutral saturated ammonium sulphate solution. The pellet was washed twice with 50\%-saturated neutral ammonium sulphate solution and finally dissolved in phosphate-buffered saline containing normal rabbit serum, volume fraction 0.10 , to obtain a concentration of $1 \mathrm{~g} / \mathrm{l}$. Aliquots were stored at $-80^{\circ} \mathrm{C}$.

\section{Analysis of the specificity of the polyclonal antibody}

Pure proteins (standard alkaline protease and exotoxin A) and culture supernatants were subjected to SDS-PAGE-electrophoresis for Western blot analysis. Discontinuous SDS gel electrophoresis was performed in a modified Laemmli (23) gel system, with a $4.5 \%$ stacking gel and a $12.5 \%$ separating gel. Transfer to the nitrocellulose sheet was performed in a Trans-Blot cell overnight at $50 \mathrm{~V}$ and $200 \mathrm{~mA}$, using transfer buffer $(20 \mathrm{mmol} / \mathrm{l}$ Tris, $150 \mathrm{mmol} / \mathrm{l}$ glycine, $200 \mathrm{ml} / \mathrm{l}$ methanol), as described by Burnette (24). The blots were then probed with antibody diluted 1 in 2000 in 0.005 $\mathrm{mol} / 1$ sodium phosphate and $0.12 \mathrm{~mol} / 1 \mathrm{NaCl}, \mathrm{pH} 8.0$, containing $100 \mathrm{ml} / \mathrm{l}$ calf serum and $30 \mathrm{ml} / \mathrm{l}$ Tween 20 . Antibody binding was detected using horseradish-peroxidase-conjugated mouse IgG against rabbit immunoblobulins; peroxidase activity was characterized using the chemiluminescent detection procedure according to the manufacturer's recommendations.

\section{Immunoassay procedure}

Microtitre plates were coated with $100 \mu \mathrm{l}$ aliquots of the non-conjugated antisera in $0.1 \mathrm{~mol} / 1$ phosphate buffer, $\mathrm{pH} 7.2$ overnight at room temperature. The concentrations were $3.7 \mathrm{mg} / \mathrm{l}$ and $1.3 \mathrm{mg} / \mathrm{l}$ for anti-alkaline protease and anti-exotoxin $\mathrm{A}$ IgG respectively. The plates were then rinsed five times with phosphate-buffered saline $0.01 \mathrm{~mol} / \mathrm{l}$, pH 7.2 and $5 \mathrm{ml} / \mathrm{l}$ Tween 20 . Coated plates could be stored at $4{ }^{\circ} \mathrm{C}$ for up to one month in phosphate-buffered saline with $5 \mathrm{ml} / \mathrm{l}$ Tween 20 . 
Culture supernatants were diluted in phosphate-buffered saline with $1 \mathrm{~g} / \mathrm{l}$ bovine serum albumin. Standard dilutions ranged from 0.3 to $25 \mu \mathrm{g} / \mathrm{l}$. Tests were performed in duplicate. Diluted samples $(100 \mu \mathrm{l})$ of supernatants or standard were added to the coated wells. After $90 \mathrm{~min}$ of incubation at room temperature, the plates were rinsed five times with phosphate-buffered saline and $5 \mathrm{ml} / 1$ Tween 20.

Aliquots $(100 \mu \mathrm{l})$ of the conjugated anti-alkaline protease and antiexotoxin A (125 mg/l) were added. The plates were incubated for $90 \mathrm{~min}$ at room temperature, and rinsed five more times with phosphate-buffered saline and $5 \mathrm{ml} / 1$ Tween 20 . Substrate solution (100 $\mu \mathrm{l}$ containing $0.1 \mathrm{~mol} / \mathrm{l}$ phosphate-citrate buffer, $\mathrm{pH} 5.5,3 \mathrm{~g} / \mathrm{l}$ ophenylene-diamine dihydrochloride; $3.5 \mathrm{mmol} / 1 \mathrm{H}_{2} \mathrm{O}_{2}$ ) was then added. The enzyme reaction was allowed to proceed for $30 \mathrm{~min}$ at room temperature in the dark. After stopping the reaction with 100 $\mu \mathrm{l}$ of $1 \mathrm{~mol} / 1 \mathrm{HCl}$, absorbances were read at $490 \mathrm{~nm}$ in a MR7000 Dynatech spectrophotometer. Standards were included on each plate; alkaline protease and exotoxin A concentrations of test specimens were calculated from a standard curve generated with known concentrations of pure protein.

Immunoenzymatic assay of Pseudomonas aeruginosa elastase

The assay was performed as described previously (19).

\section{Results}

\section{Specificity of the antibodies}

Culture supernatant fractions were analysed by immunoblotting, using SDS-PAGE. Alkaline protease (fig. 1) produced a major band at $M_{\mathrm{r}} 48000$, and a smear which was probably due to proteolysis of the protein; when a lower dose was loaded, only two bands appeared: the major one at $M_{\mathrm{r}} 48000$, the other at $M_{\mathrm{r}} 45000$; this latter form probably represents a partially degraded form of

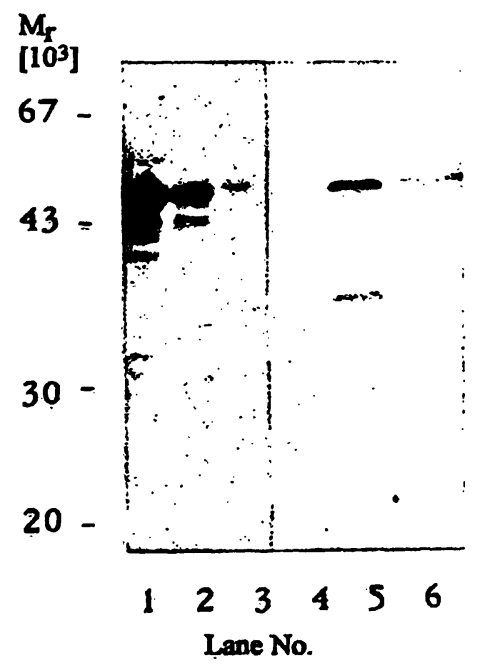

Fig. 1 Immunoreactivity of anti-alkaline protease antibody with $P$ seudomonas aeruginosa supernatants. Supernatants were submitted to SDS/PAGE before Western blotting.

Lane 1: alkaline protease $(100 \mathrm{ng})$.

Lane 2: alkaline protease $(50 \mathrm{ng})$.

Lane 3: PAO1 culture supernatant $(10 \mu \mathrm{l})$.

Lane 4: PA103 culture supernatant $(10 \mu)$.

Lanes 5 and 6: supernatants of strains isolated from 2 patients.

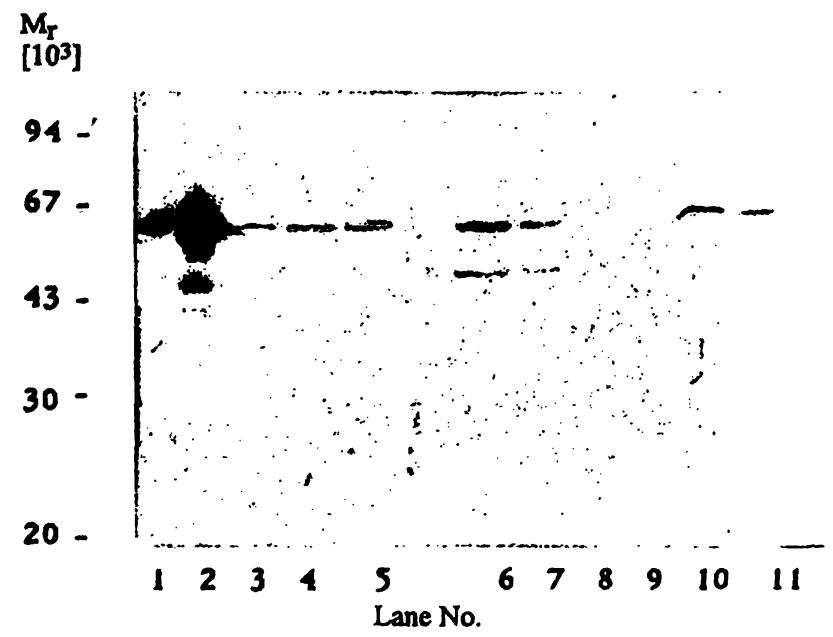

Fig. 2 Immunoreactivity of anti-exotoxin A antibody with Pseudomonas aeruginosa supernatants. Supernatants were submitted to SDS/PAGE before Western blotting.

Lane 1: exotoxin A standard (50 $\mathrm{ng}$ ).

Lane 2: exotoxin A standard ( $100 \mathrm{ng}$ ).

Lane 3: PAO1 culture supernatant $(10 \mu \mathrm{l})$.

Lane 4: PAO1 culture supernatant $(20 \mu \mathrm{l})$.

Lane 5: PA103 culture supernatant $(10 \mu \mathrm{l})$.

Lanes 6 and 7: supernatant of strain isolated from patient 1 (20 and $10 \mu \mathrm{l})$.

Lanes 8 and 9: supernatant of strain isolated from patient 2 (20 and $10 \mu \mathrm{l}$ ) showing the absence of exotoxin A secretion.

Lanes 10 and 11: supernatant of strain isolated from patient 3 (20 and $10 \mu l$ ).

the molecule. In the PAO1-cultured supernatants, only the major band appeared. This was also observed in the supernatant from one of the two patients isolates. In the protease deficient strain PA103, no band was found, as expected.

Exotoxin A (fig. 2) produced a major band at $M_{\mathrm{r}} 66000$, and a small smear, probably also corresponding to the proteolysis of the protein. In PAO1 and PA103 supernatants, only the major band was found.

\section{Optimization of the assays}

The rabbit antibodies used for the coating procedure and the horseradish peroxidase conjugates were tested at different concentrations. The antibody optimal dilution for coating was 1 in 1000 for alkaline protease, and 1 in 2000 for exotoxin A, corresponding to a concentration of $3.7 \mathrm{mg} / \mathrm{l}$ and $1.3 \mathrm{mg} / \mathrm{l}$ respectively. The conjugates were diluted until they gave an absorbance of nearly 1.5 for the highest standard volume $(25 \mu \mathrm{g} / \mathrm{l})$; this was obtained with a 1 in 8000 dilution, corresponding to a concentration of $0.125 \mathrm{mg} / \mathrm{l}$. Lower dilutions of antibody coating failed to increase sensitivity, whereas larger concentrations of conjugates increased the background signal. Test samples with an absorbance greater than 1.5 were diluted in phosphate-buffered saline, and re-assayed. The optimal incubation time of the inmu- 

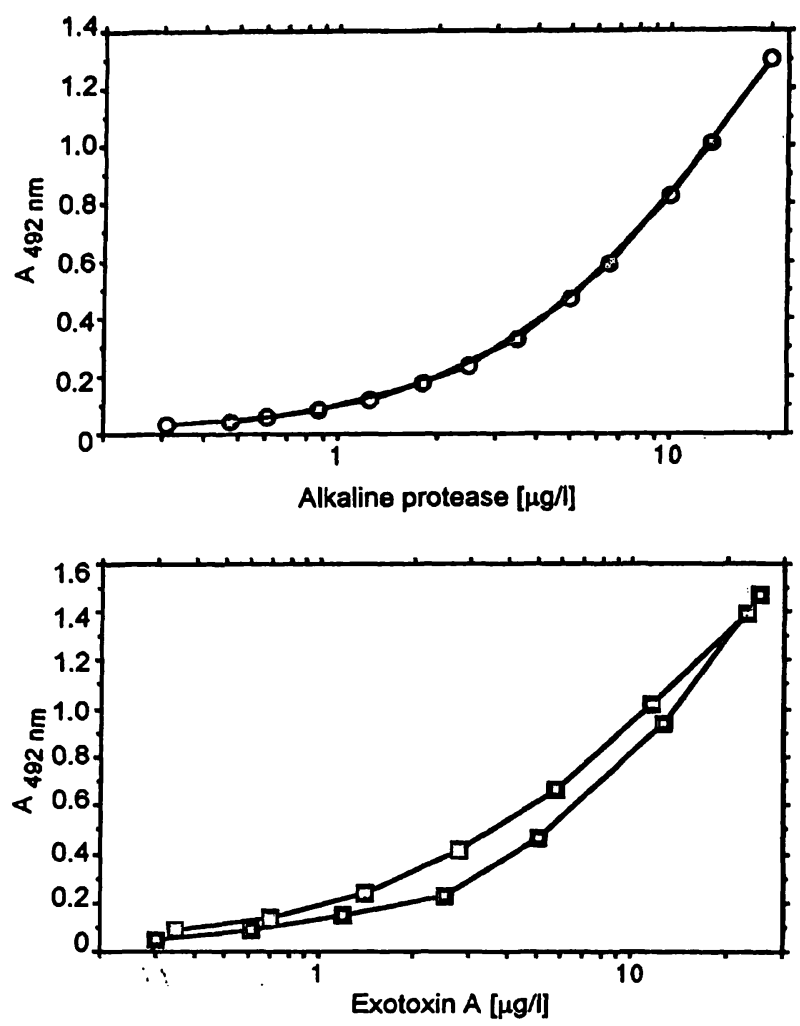

Fig. 3 Parallel standard curves obtained with

a) pure alkaline protease $(O)$ and

b) pure exotoxin $A(\square)$

and with diluted strain supernatants $(\Theta, \square)$, showing the absence of interfering reactants in the supernatants.

noreaction step was also investigated, and a $90 \mathrm{~min}$ duration was selected.

\section{Range and detection limit}

Titration curves of pure alkaline protease and exotoxin $A$ are shown in figure 3 . The useful range of the standard curve of $0.3-20 \mu \mathrm{g} / \mathrm{l}$ was chosen for subsequent assays for the two proteins.

The lower detection limit of the assays, defined as the concentration of protein corresponding to the zero standard plus 2 SD of the zero standard absorbance $(n=19)$ was $0.3 \mu \mathrm{g} / \mathrm{l}$ for alkaline protease and $0.26 \mu \mathrm{g} / \mathrm{l}$ for exotoxin A using the optimized conditions.

The control strain PAO1 secreted $5 \mathrm{mg} / \mathrm{l}$ of alkaline protease, and $120 \mu \mathrm{g} / \mathrm{l}$ of exotoxin A under the given experimental conditions. PA 103, the non-proteolytic strain, secreted $12 \mathrm{mg} / \mathrm{l}$ of exotoxin $\mathrm{A}$, and as expected, did not secrete alkaline protease.

\section{Linearity}

The linearity of the assays was checked by measuring doubling dilutions of culture supernatants $(1 / 2,1 / 4,1 / 8$, $1 / 16,1 / 32$ and 1/64) and comparing the resulting curves with the reference curves for pure protein. The relationship between absorbance and $\log$ protein concentration was nearly linear in the concentration range $0.37-20$ $\mu \mathrm{g} / \mathrm{l}$ (fig. 3).

\section{Precision (tab. 1)}

The intra-assay (within-series) coefficients of variation were calculated from repeated analyses of culture supernatants containing 6.3 and $13 \mu \mathrm{g} / 1$ of alkaline protease, and 0.8 and $3 \mu \mathrm{g} / 1$ of exotoxin $\mathrm{A}$.

The coefficients of variation were $4.2 \%$ and $3.1 \%$ for alkaline protease, and $2.9 \%$ and $4.7 \%$ for exotoxin A.

Inter-assay (day-to-day) precision for alkaline protease was tested by assaying culture supernatants at concentrations of $6.2 \mu \mathrm{g} / \mathrm{l}$ and $13.7 \mu \mathrm{g} / \mathrm{l}$ within 17 different series; coefficients of variation were $8.3 \%$ and $4.3 \%$, respectively.

This was also tested for exotoxin A by using two culture supernatants at concentrations of 5.4 and $10.8 \mu \mathrm{g} / \mathrm{l}$ within 16 different series; coefficients of variation were $5.9 \%$ and $9.4 \%$, respectively.

\section{Recovery}

Known amounts of pure alkaline protease and exotoxin A were added to a culture supernatant and the levels measured were compared with those expected. Recoveries between 90 and $118 \%$ were obtained (tab. 2).

Exoprotein productions in culture supernatants of clinical isolates obtained from cystic fibrosis expectorates

The production of alkaline protease, exotoxin $\mathrm{A}$ and elastase by 35 Pseudomonas aeruginosa strains isolated

Tab. 1 Precision data for alkaline protease and exotoxin $\mathrm{A}$ assays in culture supernatants.

\begin{tabular}{lcccc}
\hline Imprecision & $\mathrm{n}$ & $\begin{array}{l}\text { Mean } \\
(\mu \mathrm{g} / \mathrm{l})\end{array}$ & $\begin{array}{l}\text { SD } \\
(\mu \mathrm{g} / \mathrm{l})\end{array}$ & $\begin{array}{l}\mathrm{CV} \\
(\%)\end{array}$ \\
\hline $\begin{array}{l}\text { Alkaline protease } \\
\quad \text { Within-series }\end{array}$ & 20 & 6.3 & 0.27 & 4.2 \\
& 20 & 13.0 & 0.40 & 3.1 \\
Day-to-day & 17 & 6.2 & 0.52 & 8.3 \\
& 17 & 13.7 & 0.59 & 4.3 \\
& & & & \\
Exotoxin A & 15 & 0.8 & 0.02 & 2.9 \\
Within-series & 15 & 3 & 0.14 & 4.7 \\
& 16 & 5.4 & 0.30 & 5.9 \\
Day-to-day & 16 & .10 .8 & 1.01 & 9.4 \\
& & & & \\
\hline
\end{tabular}


Tab. 2 Recovery of Pseudomonas aeruginosa alkaline protease and exotoxin $A$ added to culture supernatants.

The percentage recovery was calculated as follows: \% recovery $=100 \times$ (measured/calculated values). Alkaline protease and exotoxin A were added to culture supernatants of known alkaline protease and exotoxin A concentrations, vortexed, then assayed as described.

\begin{tabular}{llll}
\hline $\begin{array}{l}\text { Concentration } \\
\text { in the sample }\end{array}$ & $\begin{array}{l}\text { Added } \\
\text { concen- } \\
\text { tration } \\
(\mu \mathrm{g} / \mathrm{l})\end{array}$ & $\begin{array}{l}\text { Measured } \\
\text { concen- } \\
\text { tration } \\
(\mu \mathrm{g} / \mathrm{l})\end{array}$ & Recovery \\
\hline
\end{tabular}

Alkaline protease

$\begin{array}{rlrr}3.2 & 2.5 & 5.4 & 94 \\ 3.2 & 5 & 8.4 & 102 \\ 3.2 & 7.5 & 9.7 & 90 \\ 3.2 & 10 & 15.6 & 118 \\ 3.2 & 12.5 & 15.2 & 96\end{array}$

\section{Exotoxin $A$}

\begin{tabular}{rrrr}
4.4 & 1.3 & 5.7 & 100 \\
4.4 & 2.5 & 7.2 & 104 \\
4.4 & 6.2 & 9.5 & 89 \\
4.4 & 12.5 & 15.6 & 92 \\
\hline
\end{tabular}

from cystic fibrosis sputum samples was determined. Correlations between the different secretions were analysed by a simple regression test.

Alkaline protease levels ranged from $0.3 \mu \mathrm{g} / \mathrm{l}$ to 27.2 $\mathrm{mg} / \mathrm{l}$, exotoxin A from $0.3 \mu \mathrm{g} / 1$ to $29.3 \mathrm{mg} / \mathrm{l}$, and elastase, from $0.3 \mu \mathrm{g} / 1$ to $116 \mathrm{mg} / \mathrm{l}$. The detailed individual values of concentrations in culture supernatants are given in table 3.

Simple linear regression analysis revealed a weak correlation between elastase and exotoxin $\mathrm{A}$ production $(r=0.697, p<0.001)$.

\section{Discussion}

With the aim of investigating the levels of different proteins secreted by Pseudomonas aeruginosa, we developed enzyme immunoassays for alkaline protease and exotoxin A of Pseudomonas aernginosa. In a previous study, we described an enzyme immunoassay for the detection of Pseudomonas aeruginosa elastase. The assays reported here for the two other proteins appeared to be as specific, as sensitive and as easily applicable as the previously developed elastase assay. The detection limits were $0.3 \mu \mathrm{g} / \mathrm{l}$ for alkaline protease and $0.26 \mu \mathrm{g} / \mathrm{l}$ for exotoxin $A$, i. e. in the same range as those of the elastase assay. Radioimmunoassays of alkaline protease (17) and exotoxin A (18) showed good lower detection limits of around one $\mu \mathrm{g} / \mathrm{l}$, but had the disadvantage of using radiolabelled products. The enzyme immunoassay for exotoxin A developed by Schultz (15) also had good sensitivity $(0.3 \mu \mathrm{g} / \mathrm{l})$, but required two different species antibodies.

The coated microtitre plates can be stored wet (with buffer) and sealed for one month at $4^{\circ} \mathrm{C}$, so that the assays are readily available, and moreover can be performed in the relatively short time of 4 hours.

The specificity of the antibodies was proved by the presence of major bands at $M_{\mathrm{r}} 48000$ for alkaline protease and at $M_{\mathrm{r}} 66000$ for exotoxin A. The little smears also present with pure proteins probably reflected some proteolysis.

The linearity between log absorbance and log protein concentrations (two-fold dilutions of culture supernatants) was good over a concentration range of $0.3-25$ $\mu \mathrm{g} / \mathrm{l}$. As shown in figure 3 , a good parallelism was noted in every case, thus suggesting an absence of non-specific interfering reactions.

Tab. 3 Elastase, exotoxin A and alkaline protease concentrations in the culture supernatants of thirty-five Pseudomonas aeruginosa strains isolated from cystic fibrosis patients.

\begin{tabular}{|c|c|c|c|}
\hline $\begin{array}{l}\text { Strains } \\
\text { no. }\end{array}$ & $\begin{array}{l}\text { Elastase } \\
(\mathrm{mg} / \mathrm{l})\end{array}$ & $\begin{array}{l}\text { Exotoxin A } \\
(\mathrm{mg} / \mathrm{l})\end{array}$ & $\begin{array}{l}\text { Alkaline } \\
\text { protease } \\
(\mathrm{mg} / \mathrm{l})\end{array}$ \\
\hline 1 & 12.06 & 21.50 & 8.40 \\
\hline 2 & 8.40 & 7.80 & 23.00 \\
\hline 3 & 3.80 & 10.50 & 0.40 \\
\hline 4 & 44.70 & 18.20 & 19.70 \\
\hline 5 & 1.35 & 5.60 & 0.50 \\
\hline 6 & 1.50 & 2.60 & 1.20 \\
\hline 7 & 2.26 & 4.48 & 6.64 \\
\hline 8 & 25.27 & 6.00 & 21.66 \\
\hline 9 & 4.21 & 4.76 & 6.21 \\
\hline 10 & 27.75 & 3.83 & 10.27 \\
\hline 11 & 2.55 & 3.23 & 1.38 \\
\hline 12 & 2.42 & 4.69 & 7.84 \\
\hline 13 & 2.68 & 1.51 & 1.08 \\
\hline 14 & 22.00 & 12.10 & 3.20 \\
\hline 15 & 10.90 & 9.60 & 3.70 \\
\hline 16 & 28.10 & 9.70 & 13.20 \\
\hline 17 & 0.82 & 0 & 0.03 \\
\hline 18 & 0 & 0 & 0 \\
\hline 19 & 0 & 0 & 0 \\
\hline 20 & 0.02 & 0.01 & 0 \\
\hline 21 & 0 & 0.01 & 0 \\
\hline 22 & 0 & 0.01 & 0 \\
\hline 23 & 10.10 & 12.80 & 5.70 \\
\hline 24 & 0.02 & 0.01 & 0.01 \\
\hline 25 & 0.92 & 15.60 & 0.80 \\
\hline 26 & 0.01 & 0.02 & 0.01 \\
\hline 27 & 0.01 & 0.01 & 0.01 \\
\hline 28 & 26.30 & 0.02 & 0.86 \\
\hline 29 & 31.50 & 0.12 & 27.20 \\
\hline 30 & 11.60 & 0.01 & 0.27 \\
\hline 31 & 65.00 & 29.30 & 26.50 \\
\hline 32 & 80.00 & 19.60 & 3.09 \\
\hline 33 & 116.00 & 20.00 & 15.30 \\
\hline 34 & 14.10 & 11.20 & 6.73 \\
\hline 35 & 8.80 & 9.50 & 8.40 \\
\hline
\end{tabular}

$0=$ not detectable 
The precision of the assay was comparable with that of elastase (tab. 1) with intra-assay coefficients of variation ranging from 3 to $5 \%$, and inter-assay coefficients of variation ranging from 5 to $10 \%$.

As observed by other authors $(2,4,16)$, we also observed a great strain variability in protein secretion in the culture supernatants. Most of the strains secreted all 3 enzymes. Five out of the 35 strains (14\%) did not secrete alkaline protease, 3 strains $(9 \%)$ did not secrete exotoxin $\mathrm{A}$ and 4 strains (11\%) did not secrete elastase. This is in accordance with results published by Mull \& Callahan (25) who showed that $86 \%$ of the Pseudomonas aeruginosa strains revealed elastolytic activity. In fact, 6 out of the 35 strains did not secrete, or secreted the three exoproteins in a very small amount (Nos. 17 to 22). Under the culture conditions used for these strains from the sputum of cystic fibrosis patients, a positive correlation was found between elastase and exo- toxin $\mathrm{A}(\mathrm{r}=0.697, \mathrm{p}<0.001)$ production, as described elsewhere (26).

From these observations, absence or loss of any one of the extracellular products (elastase, alkaline protease and exotoxin A) did not apparently affect the ability of the bacteria to colonize and persist in the lung of cystic fibrosis patients. It would be of interest to investigate the production of these exoproteins in bronchial secretions of cystic fibrosis patients, as their in vitro production could be affected by subculturing. The immunoenzymometric assays are easily applicable, and have been tested in complex biological media, such as sputum. Döring et al. (2) have shown that elastase and alkaline protease were detectable in bronchial secretions from cystic fibrosis patients who had no specific antibodies in their serum or bronchial secretions. The follow-up of the three exoproteins during bronchopulmonary exacerbation in cystic fibrosis patients chronically infected by Pseudomonas aeruginosa is under study using these methods.

\section{References}

1. Liu, P. V. (1974) Extracellular toxins of Pseudomonas aeruginosa. J. Infect. Dis. 130, Suppl., S94-S99.

2. Döring, G., Obernesser, H.-J., Botzenhart, K., Flehming, B., Hoiby, N. \& Hofmann, A. (1983) Proteases of Pseudomonas aeruginosa in patients with cystic fibrosis. J. Infect. Dis. 147, 744-750.

3. Morihara, K. \& Tsuzuki, H. (1977) Production of protease and elastase by Pseudomonas aeruginosa strains isolated from patients. Infect. Immun. 15, 679-685.

4. Pollack, M., Taylor, N. S. \& Callahan, L. T. (1977) Exotoxin production by clinical isolates of Pseudomonas aeruginosa. Infect. Immun. 15, 776-780.

5. Blackwood, L. L., Stone, R. M., Iglewski, B. H. \& Pennington, J. E. (1983) Evaluation of Pseudomonas aeruginosa exotoxin $A$ and elastase as virulence factors in acute lung infection. Infect. Immun. 39, 198-201.

6. Klinger, J. D., Straus, D. C., Hilton, C. B. \& Pennington, J. E. (1978) Antibodies to protease and exotoxin A of Pseudomonas aeruginosa in patients with cystic fibrosis: Demonstration by radioimmunoassay. J. Infect. Dis. 138, 49-58.

7. Moss, R. B., Hsu, Y.-P., Lewiston, N. J., Curd, J. G., Milgrom, H., Hart, S., Deyer, B. \& Larrick, J. W. (1986) Association of systemic immune complexes, complement activation, and antibodies to Pseudomonas aeruginosa lipopolysaccharide and exotoxin A mortality in cystic fibrosis. Am. Rev. Respir. Dis. $133,648-652$.

8. Nicas, T. I. \& Iglewski, B. H. (1985) The contribution of exoproducts to virulence of Pseudomonas aeruginosa. Can. J. Microbiol. 31, 387-392.

9. Suter, S., Schaad, U. B., Roux, L., Nydegger, U. E. \& Waldvogel, F. A. (1986) Granulocyte neutral proteases and Pseudomonas aeruginosa elastase as possible causes of airway damage in patients with cystic fibrosis. J. Infect. Dis. $149,523-531$.

10. Woods, D. E., Cryz, S. J., Friedman, R. L. \& Iglewski, B. H. (1982) Contribution of toxin $A$ and elastase to virulence of Pseudomonas aeruginosa in chronic lung infections of rats. Infect. Immun. 36, 1223-1228.

11. Hoiby, N. \& Koch, C. (1990) Pseudomonas aeruginosa infection in cystic fibrosis and its management. Thorax $45,881-$ 884.

12. Amitani, R., Wilson, R., Rutman, A., Read, R., Ward, C., Burnett, D., Stockley, R. A. \& Cole, P. J. (1991) Effects of human neutrophil elastase and Pseudomonas aeruginosa proteinases on human respiratory epithelium. Am. J. Respir. Cell. Mol. Biol. 4, 26-32.

13. Kharazmi, A. (1989) Interactions of Pseudomonas aeruginosa proteases with the cells of the immune system. Antibiot. Chemother. 42, 42-49.

14. Woods, D. E. \& Sokol, P. A. (1986) Role of Pseudomonas aeruginosa extracellular enzymes in lung disease. Clin. Invest. Med. 9, 108-112.

15. Schultz, W. W., Phipps, T. J. \& Pollack, M. (1979) Enzymelinked immunosorbent assay for Pseudomonas aeruginosa exotoxin A. J. Clin. Microbiol. 9, 705-708.

16. Cryz, S. J. \& Iglewski, B. H. (1980) Production of alkaline protease by Pseudomonas aeruginosa. J. Clin. Microbiol. 12, $131-133$.

17. Döring, G., Obernesser, H. J. \& Botzenhart, K. (1982) Extracellular toxins of Pseudomonas aeruginosa. III. Radioimmunoassay for detection of alkaline protease. Zbl. Bakt. Hyg., I. Abt. Orig. A 252, 239-247.

18. Döring, G., Goldstein, W., Röll, A., Schiotz, P. O., Hoiby, N. \& Botzenhart, K. (1985) Role of Pseudomonas aeruginosa exoenzymes in lung infections of patients with cystic fibrosis. Infect. Immun. 49, 557-562.

19. Jaffar-Bandjee, M. C., Carrere, J., Lazdunski, A.; Guy-Crottè, O. \& Galabert, C. (1993) Direct double antibody sandwich immunoassay for Pseudomonas aeruginosa elastase. J. Immunol. Methods 164, 27-32.

20. Liu, P. V. (1973) Exotoxins of Pseudomonas aeruginosa. I. Factors that influence the production of exotoxin A. J. Infect. Dis. 128, 506-513.

21. Steinbuch, M., Audran, R. \& Pejaudier, L. (1970) Isolement d'immunoglobulines $\mathrm{y} 1$ and y2 des plasmas de chèvre, de mouton et de bouf. C.R. Soc. Biol. Paris 164, 296-301.

22. Wilson, M. B. \& Nakane, P. K. (1978) Recent developments in the periodate method of conjugate horseradish peroxidase (HRPO) to antibodies. In: Immunofluorescence and Related Staining Techniques (Knapp, W., ,Holubar, K. \& Wick, G., eds.) Elsevier/North-Holland, Amsterdam, pp. 215-224. 
23. Laemmli, U. K. (1970) Cleavage of structural proteins during the assembly of the head of bacteriophage T4. Nature (Lon-. don) 227, 680-685.

24. Burnette, W. N. (1981) 'Western blotting': Electrophoresis transfer of proteins from sodium dodecyl sulphate polyacrylamide gels to unmodified nitrocellulose and radiographic detection with antibody and radioiodinated protein A. Anal. Biochem. 112, 195-200.

25. Mull, J. D. \& Callahan, W. S. (1963) Estimation of elastolytic activity of strains of Pseudomonas aeruginosa. J. Bacteriol. $85,1178-1179$.
26. Woods, D. E., Schaffer, M. S., Rabin, H. R., Campbell, G. D. \& Sokol, P. A. (1986) Phenotypic comparison of Pseudomonas aeruginosa strains isolated from a variety of clinical sites. J. Clin. Microbiol. 24, 260-264.

\section{Galabert}

CERM

Hôpital Renée Sabran

Giens

F-83406 Hyères Cedex

France 
